\title{
Hubungan Aspek Kualitas Pelayanan Dengan Kepuasan Pasien Rawat Inap
}

\author{
${ }^{1}$ Maryana*, ${ }^{2}$ Maya Christiany \\ ${ }^{1,2}$ Program Studi Ilmu Keperawatan, Stikes Citra Delima Bangka Belitung \\ *Email : maryana385@yahoo.com
}

\section{Kata kunci :}

Kepuasan Pasien, Rawat inap

Keywords :

Patient's satisfaction, Hospitaliztion

Info Artikel :

\section{Tanggal dikirim :}

11 November 2021

Tanggal direvisi :

20 Desember 2021

\section{Tanggal diterima :}

13 Januari 2022

DOI Artikel :

10.33862/citradelima. v5i2.262

Halaman : 105-112

\section{Abstrak}

Kepuasan pasien adalah salah satu indikator kualitas pelayanan yang diberikan. Tujuan penelitian ini Untuk mengetahui aspek kualitas pelayanan terhadap kepuasan pasien rawat inap Di RSUD Depati Bahrin Sungailiat Bangka. Untuk wilayah kerja di Rumah Sakit Umum Depati Bahrin Sungailiat, kepuasan pasien rawat inap meningkat 3 tahun terakhir. Pada tahun 2018 sebesar 81,50\%, pada tahun 2019 sebesar 83\%, pada tahun 2020 sebesar $84,56 \%$. Tujuan penelitian yaitu mengetahui faktor yang berhubungan dengan kepuasan pasien. Penelitian ini dilakukan dengan menggunakan desain cross sectional dan uji chi-square dengan hasil berupa analisa bivariat dan analisa univariat. Populasi penelitian yaitu pasien rawat inap pada bulan Juni 2021. Sampel penelitian yaitu sebagian besar berusia > 18 tahun dari populasi penelitian yang berjumlah 83 responden. Instrumen penelitian menggunakan kuesioner yang berisi 21 pertanyaan. Hasil penelitian diketahui ada hubungan antara kehandalan $p$ value $(0,000)$, daya tanggap $p$ value $(0,000)$, bukti fisik $p$ value $(0,029)$, jaminan $p$ value $(0,000)$, empati $p$ value $(0,038)$ dengan kepuasan pasien dalam pelayanan rawatinap. Saran dari penelitian ini adalah meningkatkan kinerja maupun kualitas dari faktor kehandalan, daya tanggap, bukti fisik, jaminan, dan empati agar indikator kepuasan pasien rawat inap meningkat.

\section{Relationship Of Service Quality Aspects Towards Inpatient Patient Satisfaction}

Abstract
Patient satisfaction is one indicator of success obtained from the patients. The standard of
outpatient satisfaction according to the Ministry of Health in 2016 is above $90 \%$. Patient
satisfaction is one indicator of the quality of services we provide and patient satisfaction
is a capital to get more patients and to get loyal patients. The purpose of this study was to
determine the aspect of service quality on the satisfaction of inpatients at the
DepatiBahrin Hospital Sungailiat Bangka. For the work area at the Depati Bahrin Sungai
liat General Hospital, inpatient satisfaction has increased in the last 3 years. In 2018 it
was $81.50 \%$, in 2019 it was $83 \%$, in 2020 it was $84.56 \%$. This study was conducted using
a cross sectional design and chi-square test with the results in the form of bivariate
analysis and univariate analysis. The research population is hospitalized patients in June
2021. The research sample is mostly aged > 18 years from the study population, which
amounted to 83 respondents. The research instrument used a questionnaire containing 21
questions. The results showed that there was a relationship between reliability p value
(0.000), responsiveness p-value (0.000), physical evidence p-value (0.029), assurance p-
value (0.000), empathy p-value (0.038) and patient satisfaction in inpatient services.
Suggestions from this study are to improve the performance and quality of the factors of
reliability, responsiveness, physical evidence, assurance, and empathy so that inpatient
satisfaction indicators increase.




\section{PENDAHULUAN}

Saat ini perkembangan sektor jasa semakin meningkat, kontribusi sektor jasa bagi pertumbuhan ekonomi tidak kalah dibandingkan dengan sektor lainnya. Oleh karena itu tingkat kualitas sistem pelayanan industri jasa harus selalu ditingkatkan untuk menciptakan keunggulan kompetitif. Rumah sakit berpegang pada misi sosial untuk menyembuhkan orang sakit. Disisi lain rumah sakit juga berfungsi sebagai tempat berbagi profesi melakukan kegiatan untuk mencari nafkah, serta menjadi tempat berbagai kegiatan mencari keuntungan, misalnya dari penjualan obat atau pemakaian peralatan kedokteran. Begitu juga yang dilakukan pada usaha rumah sakit, semakin disadari bahwa pelayanan dan kepuasan merupakan aspek vital di dalamnya (Puspa, 2013).

Kepuasan adalah persepsi terhadap produk atau jasa yang telah memenuhi harapannya. Jadi kepuasan pelanggan adalah hasil dari akumulasi konsumen atau pelanggan dalam menggunakan produk atau jasa tersebut (Nursalam, 2018). Kepuasan pasien adalah salah satu indikator kualitas pelayanan yang kita berikan dan kepuasan pasien adalah suatu modal untuk mendapatkan pasien lebih banyak lagi dan untuk mendapatkan pasien yang loyal (Nursalam, 2018).

Kepuasan pasien dapat dicapai dengan meningkatkan perilaku caring perawat (Tiara \& lestari, 2017). Tingkat kepuasan pasien yang akurat sangat dibutuhkan dalam upaya peningkatan mutu layanan kesehatan, karena layanan kesehatan menjadi pasar yang semakin kompetitif, mempelajari pengalaman pasien tentu dapat membantu praktisi untuk lebih baik mencakup perspektif pasien dalam pemberian layanan dan meningkatkan kepuasan pasien (Ng \& luk, 2018). Berdasarkan Keputusan Menteri Kesehatan (Kepmenkes) Nomor 129 Tahun 2008 tentang standar pelayanan minimal rumah sakit Indikator standar kepuasan pelanggan di pelayanan rawat inap idealnya harus $\geq 90 \%$.

Mewujudkan kepuasan pasien terhadap pelayanan keperawatan tentunya mengacu pada berbagai faktor. Menurut Sangadji (2013) mengatakan ada 5 faktor yaitu : karakteristik pasien, bentuk fisik, jaminan, kepedulian, kehandalan. Dan menurut Muninjaya (2011) juga ada 5 faktor yang mempengaruhi kepuasan pasien yaitu ; cepat tanggap (responsiveness), kehandalan (reliability), jaminan (assurance), empati (empathy), bukti fisik (tangible).
Dengan faktor tersebut pasien dapat menilai bagaimana pelayanan keperawatan yang diterimanya serta dapat mempersepsikan apakah sesuai dengan yang diinginkan oleh pasien tersebut atau tidak.

Karakteristik Menurut Parasuraman (Nursalam; 2011), kualitas pelayanan perawat memiliki beberapa aspek, yaitu:

1. Kehandalan (reliability), yaitu kemampuan untuk memberikan pelayanan yang tepat dan terpercaya Pelayanan yang terpercaya artinya adalah konsisten. Sehingga reliability mempunyai dua aspek penting yaitu kemampuan memberikan pelayanan seperti yang dijanjikan dan seberapa jauh mampu memberikan pelayanan yang tepat atau akurat.

2. Daya tanggap (Responsiveness), yaitu kesediaan atau kemauan untuk membantu pelanggan dan memberikan pelayanan yang cepat.

3. Jaminan kepastian (Assurance), yaitu mencakup pengetahuan, kompetensi, kesopanan, dan sifat dapat dipercaya yang dimiliki staf (bebas dari bahaya, risiko atau keragu-raguan).

4. Empati (Emphaty), yaitu membina hubungan yang baik, pemahaman atas kebutuhan individual para pelanggan, dan memberikan pelayanan serta perhatian secara individual pada pelanggannya.

5. Bukti langsung (Tangible), yang meliputi fasilitas fisik, peralatan, pegawai, dan media komunikasi yang dapat dirasakan langsung oleh pelanggan.

Penelitian tentang Faktor-faktor yang berhubungan dengan Kepuasan Pasien di Instalasi Rawat Inap RSUD Dr. Achmad Mochtar sedikit dibawah Standar Pelayanan Minimum Instalasi Rawat Inap Rumah Sakit yang ditetapkan yaitu sebesar $90 \%$. Penelitian ini bertujuan untuk melihat faktor-faktor yang mempengaruhi kepuasan pasien, yaitu komunikasi, reliability, responsiveness dan melihat hubungan antara faktor-faktor tersebut dengan kepuasan pasien. Hasil penelitian ini, 96,5\% komunikasi perawat baik, 94,1\% Reliability perawat baik, $97,6 \%$ responsiveness perawat baik dan $87,1 \%$ pasien mendapatkan kepuasan. Terdapat hubungan yang bermakna antara komunikasi perawat dengan tingkat kepuasan pasien dengan $\mathrm{p}$ value $=0,043$. Terdapat hubungan antara reliability perawat dengan tingkat kepuasan pasien dengan $\mathrm{p}$ value $=0,000$. Terdapat hubungan antara responsiveness perawat dengan tingkat kepuasan pasien dengan $\mathrm{p}$ value $=0,015$. Kesimpulan dari penelitian ini adalah terdapat hubungan yang bermakna antara komunikasi, reliability (kehandalan), responsiveness (daya tanggap), dengan kepuasan 
pasien. Adapun saran bagi rumah sakit yaitu, rumah sakit harus selalu mengutamakan kepuasan pasien (Aulia Putri dkk, 2014).

Berdasarkan data rekam medik Rumah Sakit Umum Daerah Depati Bahrin Sungailiat Bangka, jumlah kunjungan pasien masuk di ruang rawat inap pada tahun 2018 sebanyak 7199 orang, tahun 2019 meningkat sebanyak 8565 orang, tahun 2020 menurun sebanyak 5163 orang. Tingkat kepuasan masyarakat dapat diperoleh dari hasil Indeks Kepuasan Masyarakat (IKM). Hasil dari data IKM yang di dapatkan pada tanggal 24 Febuari 2021 - 9 Maret 2021 bahwa tingkat kepuasan pasien atas pelayanan di ruang rawat inap pada tahun 2018 sebanyak 81,50\%, tahun 2019 sebanyak 83,00\%, dan pada tahun 2020 sebanyak $84,56 \%$, namun Hal ini masuk dalam kriteria baik namun belum mencapai Standar Pelayanan Minimal (SPM) rawat inap yaitu sebesar $\geq 90 \%$.

\section{METODE}

Jenis penelitian ini menggunakan study deskriptif dengan pendekatan Cross Sectional yaitu suatu penelitian untuk mempelajari hubungan antara variabel dimana pengukuran pada setiap subjek dilakukan pada waktu yang sama. Jumlah sampel dalam penelitian ini adalah 83 responden. Penelitian ini dilakukan di RSUD Depati Bahrin Sungailiat pada pasien rawat inap di ruangan (Aster, Seruni, Merpati, Melati, kenanga, dan Asoka) Juli tahun 2021. Kriteria inklusi adalah (1) pasien dengan minimal hari rawat 2 hari. (2) mampu baca tulis.

\section{HASIL DAN PEMBAHASAN}

Hasil

Analisa Univariat

Tabel 1. Distribusi Frekuensi Responden Berdasarkan Kepuasan Pasien Rawat Inap Di RSUD Depati Bahrin Sungailiat Tahun 2021.

\begin{tabular}{clcc}
\hline No & $\begin{array}{l}\text { Kepuasan Pasien } \\
\text { Rawat Jalan }\end{array}$ & $\begin{array}{c}\text { Jumlah } \\
\text { (orang ) }\end{array}$ & $\begin{array}{c}\text { Persentase } \\
(\%)\end{array}$ \\
\hline 1 & Tidak Puas & 50 & 60,2 \\
2 & Puas & 33 & 39,8 \\
\hline & Jumlah & 83 & 100,0 \\
\hline
\end{tabular}

Pada Tabel 1 menunjukan bahwa responden yang tidak puas sebanyak 50 orang $(60,2 \%)$ sedangkan responden yang puas sebanyak 33 orang $(39,3 \%)$.
Tabel 2. Distribusi Frekuensi Responden Berdasarkan Kehandalan Di RSUD Depati Bahrin Sungailiat Tahun 2021.

\begin{tabular}{llcc}
\hline No & Kehandalan & $\begin{array}{c}\text { Jumlah } \\
\text { (orang ) }\end{array}$ & Persentase (\%) \\
\hline 1 & Kurang Baik & 43 & 51,8 \\
2 & Baik & 40 & 48,2 \\
\hline & Jumlah & 83 & 100,0 \\
\hline
\end{tabular}

Pada table 2 menunjukkan bahwa sebagian besar Kehandalan kurang baik yaitu berjumlah 43 orang $(51,8 \%)$ dibandingkan dengan baik.

Tabel 3. Distribusi Frekuensi Responden Berdasarkan Daya Tanggap Di RSUD Depati Bahrin Sungailiat Tahun 2021.

\begin{tabular}{llcc}
\hline No & $\begin{array}{l}\text { Daya } \\
\text { Tanggap }\end{array}$ & $\begin{array}{c}\text { Jumlah } \\
\text { (orang ) }\end{array}$ & Persentase (\%) \\
\hline 1 & Kurang Baik & 45 & 54,2 \\
2 & Baik & 38 & 45,8 \\
\hline & Jumlah & 83 & 100,0 \\
\hline
\end{tabular}

Pada table 3 menunjukkan bahwa sebagian Daya Tanggap kurang baik yaitu berjumlah 45 orang $(54,2 \%)$ dibandingkan dengan yang baik yaitu 38 orang $(45,8 \%)$.

Tabel 4. Distribusi Frekuensi Responden Berdasarkan Bukti Fisik Di RSUD Depati Bahrin Sungailiat Tahun 2021.

\begin{tabular}{|c|c|c|c|}
\hline No & Bukti Fisik & $\begin{array}{l}\text { Jumlah } \\
\text { (orang ) }\end{array}$ & Persentase $(\%)$ \\
\hline 1 & $\begin{array}{l}\text { Kurang } \\
\text { Baik }\end{array}$ & 36 & 43,4 \\
\hline \multirow[t]{2}{*}{2} & Baik & 47 & 56,6 \\
\hline & Jumlah & 83 & 100,0 \\
\hline
\end{tabular}

Pada tabel 4 menunjukkan bahwa sebagian besar Bukti Fisik kurang baik yaitu berjumlah 36 orang $(43,3 \%)$ dibandingkan dengan responden yang mengatakan baik yaitu 47 orang $(56,6 \%)$.

Tabel 5. Distribusi Frekuensi Responden Berdasarkan Jaminan Di RSUD Depati Bahrin Sungailiat Tahun 2021.

\begin{tabular}{llcc}
\hline No & Jaminan & $\begin{array}{c}\text { Jumlah } \\
\text { (orang) }\end{array}$ & Persentase (\%) \\
\hline 1 & Kurang Baik & 33 & 39,8 \\
2 & Baik & 50 & 60,2 \\
\hline & Jumlah & 83 & 100,0 \\
\hline
\end{tabular}


Pada tabel 5 menunjukkan bahwa sebagian besar jaminan responden kurang baik berjumlah 33 orang $(39,8 \%)$ dibandingkan dengan responden yang mengatakan baik.

Tabel 6. Distribusi Frekuensi Responden Berdasarkan Empati Langsung Di RSUD Depati Bahrin Sungailiat Tahun 2021.

\begin{tabular}{llcc}
\hline No & Empati & $\begin{array}{c}\text { Jumlah } \\
\text { (orang) }\end{array}$ & Persentase (\%) \\
\hline 1 & Kurang Baik & 38 & 45,8 \\
2 & Baik & 45 & 54,2 \\
\hline & Jumlah & 83 & 100,0 \\
\hline
\end{tabular}

Pada tabel 6 menunjukkan bahwa sebagian kecil empati kurang baik berjumlah 38 responden $(45,8 \%)$.

\section{Analisa Bivariat}

Tabel 7. Hubungan Kehandalan Dengan Kepuasan Pasien Rawat Inap Di RSUD Depati Bahrin Sungailiat Tahun 2021.

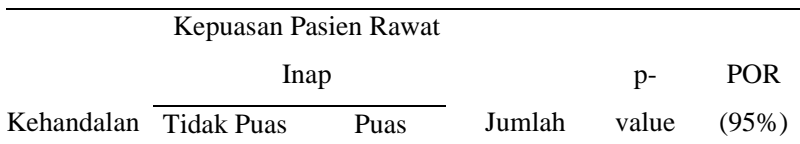

\begin{tabular}{lcccccccc}
\hline & $\mathrm{N}$ & $\%$ & $\mathrm{~N}$ & $\%$ & $\mathrm{~N}$ & $\%$ & & \\
\cline { 1 - 5 } Kurang Baik & 35 & 81,4 & 8 & 18,6 & 43 & 100 & & 7.292 \\
\hline Baik & 15 & 37,5 & 25 & 62,5 & 40 & 100 & 0,000 & $(2.683-$ \\
\cline { 1 - 5 } Total & 50 & 60,2 & 33 & 39,8 & 83 & 100 & & $29.818)$ \\
\hline
\end{tabular}

Dari hasil uji statistik Chi-Square diperoleh nilai $\mathrm{P}$

$=0,000$ sehingga dapat disimpulkan bahwa ada hubungan bermakna antara kehandalan dengan kepuasan pasien rawat inap. Hasil analisa lebih lanjut didapatkan nilai OR $=7,292$ berarti perawat yang handal cenderung meningkatkan kepuasan pasien sebesar 7,292 kali lebih besar dibandingkan dengan kehandalan yang kurang baik.

Tabel 8. Hubungan Daya Tanggap Dengan Kepuasan Pasien Rawat Inap Di RSUD Depati Bahrin Sungailiat Tahun 2021.

\begin{tabular}{|c|c|c|c|c|c|}
\hline \multirow{3}{*}{$\begin{array}{l}\text { Daya } \\
\text { Tanggap }\end{array}$} & \multicolumn{3}{|c|}{ Kepuasan Pasien } & \multirow[b]{2}{*}{ Nilai } & \multirow{3}{*}{$\begin{array}{c}\text { POR } \\
(95 \%)\end{array}$} \\
\hline & & t Inap & & & \\
\hline & $\begin{array}{l}\text { Tidak } \\
\text { Puas }\end{array}$ & Puas & Jumlah & $\begin{array}{c}\mathrm{p} \\
\text { value }\end{array}$ & \\
\hline
\end{tabular}

\begin{tabular}{lcccccccc}
\hline & $\mathrm{N}$ & $\%$ & $\mathrm{~N}$ & $\%$ & $\mathrm{~N}$ & $\%$ & & \\
\hline $\begin{array}{lcccccccc}\text { Kurang } \\
\text { Baik }\end{array}$ & 38 & 84,4 & 71 & 5,6 & 43 & 100 & & $\begin{array}{l}11.762 \\
4.086-\end{array}$ \\
\hline Baik & 12 & 31,6 & 26 & 68,4 & 40 & 100 & & $33.855)$ \\
\cline { 1 - 6 } Total & 50 & 60,2 & 33 & 39,8 & 83 & 100 & & \\
\hline
\end{tabular}

Dari hasil uji statistik Chi-Square diperoleh nilai $\mathrm{P}$ $=0,000$ sehingga dapat disimpulkan bahwa ada hubungan bermakna antara daya tanggap dengan kepuasan pasien rawat inap. Hasil analisa lebih lanjut didapatkan nilai $\mathrm{OR}=11,762$ berarti daya tanggap yang baik memiliki kecenderungan kepuasan pasien 11,762 kali lebih besar dibandingkan dengan daya tanggap yang kurang baik.

Tabel 9. Hubungan Bukti Fisik Dengan Kepuasan Pasien Rawat Inap Di RSUD Depati Bahrin Sungailiat Tahun 2021.

\begin{tabular}{|c|c|c|c|c|c|c|c|}
\hline \multirow{4}{*}{$\begin{array}{l}\text { Bukti } \\
\text { fisik }\end{array}$} & \multicolumn{5}{|c|}{ Kepuasan Pasien Rawat } & \multirow{4}{*}{$\begin{array}{c}\text { Nilai } \\
\mathrm{p} \\
\text { value }\end{array}$} & \multirow{4}{*}{$\begin{array}{l}\text { POR } \\
(95 \%)\end{array}$} \\
\hline & \multicolumn{4}{|c|}{ Inap } & \multirow{3}{*}{ Jumlah } & & \\
\hline & Tidal & & Puas & & & & \\
\hline & Puas & & & & & & \\
\hline & $\mathrm{N}$ & $\%$ & $\mathrm{~N}$ & $\%$ & $\%$ & & \\
\hline Kurang & 27 & 75,0 & 9 & 25,0 & $36 \quad 100$ & & $3.130(1$ \\
\hline Baik & & & & & & 0,029 & $215-$ \\
\hline Baik & 23 & 48,9 & 24 & 51,1 & $47 \quad 100$ & & $8.067)$ \\
\hline Total & 50 & 60,2 & 33 & 39,8 & $83 \quad 100$ & & \\
\hline
\end{tabular}

Dari hasil uji statistik Chi-Square diperoleh nilai $\mathrm{P}$ $=0,029$ sehingga dapat disimpulkan bahwa ada hubungan bermakna antara bukti fisik dengan kepuasan pasien rawat inap. Hasil analisa lebih lanjut didapatkan nilai $\mathrm{OR}=3,130$, berarti bukti fisik yang baik memiliki kecenderungan kepuasan pasien 3,130 kali lebih besar dibandingkan dengan bukti fisik yang kurang baik.

Tabel 10. Hubungan Jaminan Dengan Kepuasan Pasien Rawat Inap Di RSUD Depati Bahrin Sungailiat Tahun 2021.

\begin{tabular}{|c|c|c|c|c|c|c|c|c|}
\hline \multirow{3}{*}{ Jaminan } & \multicolumn{4}{|c|}{ Kepuasan Pasien Rawat } & & & \multirow[b]{2}{*}{ Nilai } & \multirow{3}{*}{$\begin{array}{c}\text { POR } \\
(95 \%)\end{array}$} \\
\hline & \multicolumn{4}{|c|}{ Inap } & \multirow{2}{*}{\multicolumn{2}{|c|}{ Jumlah }} & & \\
\hline & \multicolumn{2}{|c|}{ Tidak Puas } & \multicolumn{2}{|c|}{ Puas } & & & $\begin{array}{c}\mathrm{p} \\
\text { value }\end{array}$ & \\
\hline & $\mathrm{N}$ & $\%$ & $\mathrm{~N}$ & $\%$ & $\mathrm{~N}$ & $\%$ & & \\
\hline Kurang & 28 & 84,8 & 5 & 15,2 & 33 & 100 & & $7.127(2$. \\
\hline Baik & & & & & & & 0,000 & $365-$ \\
\hline Baik & 22 & 44,0 & 28 & 56,0 & 50 & 100 & & 21.483) \\
\hline Total & 50 & 60,2 & 33 & 39,8 & 83 & 100 & & \\
\hline
\end{tabular}

Dari hasil uji statistik Chi-Square diperoleh nilai $\mathrm{P}=0,000$ sehingga dapat disimpulkan bahwa ada hubungan bermakna antara jaminan dengan kepuasan pasien rawat inap. Hasil analisa lebih lanjut didapatkan nilai $\mathrm{OR}=7,127$, berarti jaminan yang baik memiliki kecenderungan kepuasan pasien 7,127 kali lebih besar dibandingkan dengan jaminan yang kurang baik.

http://jurnalilmiah.stikescitradelima.ac.id/index.php/JI Vol.5 No.2 Januari 2022 
Tabel 11. Hubungan Empati Dengan Kepuasan Pasien Rawat Inap Di RSUD Depati Bahrin Sungailiat Tahun 2021

\begin{tabular}{|c|c|c|c|c|c|c|c|c|}
\hline \multirow[t]{5}{*}{ Empati } & \multicolumn{4}{|c|}{ Kepuasan Pasien } & \multirow{4}{*}{\multicolumn{2}{|c|}{ Jumlah }} & \multirow{4}{*}{$\begin{array}{c}\text { Nilai } \\
\mathrm{p} \\
\text { value }\end{array}$} & \multirow{4}{*}{$\begin{array}{l}\text { POR } \\
(95 \%)\end{array}$} \\
\hline & \multicolumn{4}{|c|}{ Rawat Inap } & & & & \\
\hline & \multirow{2}{*}{\multicolumn{2}{|c|}{$\begin{array}{l}\text { Tidak } \\
\text { Puas }\end{array}$}} & \multirow{2}{*}{\multicolumn{2}{|c|}{ Puas }} & & & & \\
\hline & & & & & & & & \\
\hline & $\mathrm{N}$ & $\%$ & $\mathrm{~N}$ & $\%$ & $\mathrm{~N}$ & $\%$ & & \\
\hline Kurang & 28 & 73,7 & 10 & 26,3 & 38 & 100 & 0,038 & $2.927(1$. \\
\hline Baik & & & & & & & & $156-$ \\
\hline Baik & 22 & 48,9 & 23 & 51,1 & 45 & 100 & & 7.412) \\
\hline Total & 50 & 60,2 & 33 & 39,8 & 83 & 100 & & \\
\hline
\end{tabular}

Dari hasil uji statistik Chi-Square diperoleh nilai $\mathrm{P}$ $=0,038$, sehingga dapat disimpulkan bahwa ada hubungan bermakna antara empati dengan kepuasan pasien rawat inap. Hasil analisa lebih lanjut didapatkan nilai $\mathrm{OR}=2,927$ berarti perawat yang empati meningkatkan kepuasan pasien 2,927 kali lebih besar dibandingkan dengan empati yang kurang baik.

\section{PEMBAHASAN}

Hubungan Kehandalan Dengan Kepuasan Pasien Dalam Pelayanan Rawat Inap Di RSUD Depati Bahrin Sungailiat Tahun 2021.

Kehandalan (reliability), yaitu kemampuan untuk memberikan pelayanan yang tepat dan terpercaya. Pelayanan yang terpercaya artinya adalah konsisten. Sehingga reliability mempunyai dua aspek penting yaitu kemampuan memberikan pelayanan seperti yang dijanjikan dan seberapa jauh mampu memberikan pelayanan yang tepat atau akurat (Nursalam, 2011). Reliability, mencakup dua hal pokok, yaitu konsistensi kerja dan kemampuan untuk dipercaya. Hal ini berarti pelayanan kesehatan memberikan jasa secara tepat sejak saat pertama dan memenuhi janjinya, seperti memberikan pelayanan sesuai jadwal yang disepakati (Irene D. Sari, 2010).

Dari hasil penelitian analisa bivariat yang telah dilakukan oleh peneliti dengan menggunakan uji statistik Chi-Square menunjukkan bahwa adanya hubungan yang bermakna antara aspek kehandalan dengan kepuasan pasien di ruang rawat inap Rumah Sakit Umum Daerah Depati Sungailiat Bangka Tahun 2021. Secara statistik terbukti hasil dari hasil Uji ChiSquare dengan nilai ( $p$ Value $=0,000, \mathrm{OR}=7,292$ ). perawat yang handal cenderung meningkatkan kepuasan pasien 7,292 kali lebih besar dibandingkan dengan kehandalan yang kurang baik.
Penelitian ini sejalan dengan penelitian yang dilakukan oleh Siama, dkk (2017) yang menunjukan bahwa ada hubungan kepuasan pasien dengan kehandalan di Rumah Sakit Umum Daerah Tamiang Layang diperoleh nilai ( $\mathrm{p}$ value $=0,001$ ), informasi lebih lanjut diketahui bahwa responden yang memiliki persepsi baik dan puas terhadap kepuasan pasien dimensi kehandalan (reliability) yang diberikan ada sebanyak 45 responden $(97,8 \%)$ sedangkan responden yang memiliki persepsi baik tapi tidak puas terdapat sebanyak 1 responden $(2,2 \%)$. Responden yang memiliki persepsi tidak baik tapi puas sebanyak 1 responden $(16,7 \%)$, sedangkan responden yang memiliki persepsi tidak baik dan tidak puas ada sebanyak 5 responden $(83,3 \%)$.

Hubungan Daya Tanggap Dengan Kepuasan Pasien Dalam Pelayanan Rawat Inap Di RSUD Depati Bahrin Sungailiat Tahun 2021.

Daya tanggap (Responsiveness), yaitu kesediaan atau kemauan untuk membantu pelanggan dan memberikan pelayanan yang cepat (Nursalam; 2011). Responsiveness, yaitu kemanusiaan atau kesiapan para petugas untuk memberikan pelayanan yang dibutuhkan pasien (Irene D. Sari 2010). Responsiveness ( daya tanggap ) yaitu keinginan para karyawan dalam memberikan pelayanan dengan tanggap (Parasuraman, 2017).

Hasil penelitian ini diperoleh informasi secara statistik ada hubungan antara daya tanggap dengan kepuasan pasien rawat inap di Rumah Sakit Umum Daerah Depati Bahrin Sungailiat Bangka Tahun 2021 ( $\mathrm{p}$ value $=0,000, \mathrm{OR}=11,762)$ daya tanggap yang baik memiliki kecenderungan kepuasan pasien 11,762 kali lebih besar dibandingkan dengan daya tanggap yang kurang baik.

Penelitian ini sejalan dengan penelitian yang dilakukan oleh Wowor, dkk (2019) yang menunjukan ada hubungan kepuasan pasien dengan daya tanggap di ruang rawat inap Rumah Sakit Cantia Tampaso Baru diperoleh nilai $(\mathrm{p}$ value $=$ $0,007)$ dengan kepuasan pasien puas berjumlah 37 responden $(40,7 \%)$ dan ketanggapan kurang baik dengan kepuasan pasien puas berjumlah 26 responden $(28,6 \%)$ sedangkan kepuasan pasien kurang puas dengan ketanggapan baik berjumlah 10 Jurnal responden $(11,0)$ dan kepuasan pasien kurang puas dengan ketanggapan kurang baik berjumlah 18 responden $(19,8 \%)$.

http://jurnalilmiah.stikescitradelima.ac.id/index.php/JI Vol.5 No.2 Januari 2022 
Hasil uji menggunakkan uji chi-square diperoleh nilai probabilitas yaitu 0,043 yang artinya menunjukkan bahwa ada hubungan antara ketanggapan dengan kepuasan pasien di rumah sakit Cantia Tompaso Baru.

Penelitian ini sejalan dengan penelitian yang dilakukan oleh Mutiara, dkk (2018) yang menunjukan ada hubungan kepuasan pasien dengan daya tanggap di ruang rawat inap Rumah Sakit dr. H. Abdul Moeloek diperoleh nilai ( $\mathrm{p}$ value $=0,027$ ) dengan 60 responden didapatkan 23 responden yang menyatakan reliability baik dan puas terhadap pelayanan rawat inap $(79,3 \%)$ sedangkan responden yang menyatakan reliability kurang baik dan tidak puas terhadap pelayanan rawat inap sebanyak 16 orang $(51,6 \%)$.

\section{Hubungan Bukti Fisik Dengan Kepuasan Pasien Rawat Inap Dalam Pelayanan Rawat Jalan Di RSUD Depati Bahrin Sungailiat Tahun 2021.}

Bukti Fisik (Tangible), yang meliputi fasilitas fisik, peralatan, pegawai, dan media komunikasi yang dapat dirasakan langsung oleh pelanggan (Nursalam; 2011). Bukti fisik yang berupa fasilitas rumah sakit sangat berpengaruh terhadap kepuasan pasien (Mongkaren, 2013).

Hasil penelitian ini diperoleh informasi secara statistik ada hubungan antara bukti fisik dengan kepuasan pasien rawat inap di Rumah Sakit Umum Daerah Depati Bahrin Sungailiat Bangka Tahun $2021(\mathrm{p}$ value $=0,029$, POR $=3.130)$ bukti fisik yang baik memiliki kecenderungan kepuasan pasien 3,130 kali lebih besar dibandingkan dengan bukti fisik yang kurang baik.

Penelitian ini sejalan dengan penelitian yang dilakukan oleh Siama, dkk (2017) yang menunjukan bahwa ada hubungan kepuasan pasien dengan bukti fisik di Rumah Sakit Umum Daerah Tamiang Layang diperoleh nilai ( $\mathrm{p}$ value $=0,001$ ), hal ini juga diperkuat dengan diketahui bahwa responden yang memiliki persepsi baik dan puas terhadap dimensi bukti fisik (tangible) yang diberikan ada sebanyak 39 responden $(97,5 \%)$ sedangkan responden yang memiliki persepsi baik tapi tidak puas terdapat sebanyak 1 responden (2,5\%). Responden yang memiliki persepsi tidak baik tapi puas sebanyak 1 responden $(8,3 \%)$, sedangkan responden yang memiliki persepsi tidak baik tapi puas sebanyak 1 responden $(8,3 \%)$, sedangkan responden yang memiliki persepsi tidak baik dan tidak puas ada sebanyak 11 responden $(91,7 \%)$. Penelitian ini sejalan dengan penelitian yang dilakukan oleh Mutiara, dkk (2018) yang menunjukan ada hubungan kepuasan pasien dengan daya tanggap di ruang rawat inap Rumah Sakit dr. H. Abdul Moeloek diperoleh nilai ( $\mathrm{p}$-value $=0,013$ ), dengan 60 responden didapatkan 26 responden yang menyatakan tangible baik dan puas terhadap pelayanan rawat inap $(78,8 \%)$ sedangkan responden yang menyatakan tangible kurang baik dan tidak puas terhadap pelayanan rawat inap sebanyak 15 orang $(55,6 \%)$.

\section{Hubungan Jaminan Dengan Kepuasan Pasien Dalam Pelayanan Rawat Inap Di RSUD Depati Bahrin Sungailiat Tahun 2021.}

Jaminan kepastian (Assurance), yaitu mencakup pengetahuan, kompetensi, kesopanan, dan sifat dapat dipercaya yang dimiliki staf (bebas dari bahaya, risiko atau keragu-raguan) (Nursalam; 2011). Jaminan (assurance) adalah jaminan kepada konsumen mencakup kemampuan, kesopanan dan sifat dapat dipercaya yang dimiliki oleh staf, bebas dari bahaya atau resiko keragu-raguan, perilaku para karyawan diharapkan dapat menumbuhkan rasa aman bagi pelanggannya (Parasuraman, 2017).

Hasil penelitian ini diperoleh informasi secara statistik ada hubungan antara jaminan dengan kepuasan pasien rawat inap di Rumah Sakit Umum Daerah Depati Bahrin Sungailiat Bangka Tahun 2021 ( $\mathrm{p}$ value $=0,000$, OR $=7.127$ ) jaminan yang baik memiliki kecenderungan kepuasan pasien 7,127 kali lebih besar dibandingkan dengan jaminan yang kurang baik.

Penelitian ini didukung oleh penelitian Siama, dkk ( 2017) yang menunjukan bahwa ada hubungan kepuasan pasien dengan jaminan di Rumah Sakit Umum Daerah Tamiang Layang diperoleh nilai ( $p$ value $=0,001$ ), hal ini juga diperkuat dengan diketahui 52 pasien yang menjadi responden, bahwa responden yang memiliki persepsi baik dan puas terhadap mutu pelayanan dalam dimensi jaminan yang diberikan ada sebanyak 45 responden $(97,8 \%)$ sedangkan responden yang memiliki persepsi baik tapi tidak puas terdapat sebanyak 1 responden $(2,2 \%)$.

Penelitian ini sejalan dengan penelitian yang dilakukan oleh Mutiara, dkk (2018) yang menunjukan ada hubungan kepuasan pasien dengan daya tanggap di ruang rawat inap Rumah Sakit dr. H. Abdul Moeloek diperoleh nilai ( $p$ value $=0,000$ )

http://jurnalilmiah.stikescitradelima.ac.id/index.php/JI Vol.5 No.2 Januari 2022 
dengan 60 responden didapatkan 32 responden yang menyatakan assurance baik dan puas terhadap pelayanan rawat inap $(86,5 \%)$ sedangkan responden yang menyatakan assurance kurang baik dan tidak puas terhadap pelayanan rawat inap sebanyak 17 orang $(73,9 \%)$

\section{Hubungan Empati Dengan Kepuasan Pasien Dalam Pelayanan Rawat Inap Di RSUD Depati Bahrin Sungailiat Tahun 2021.}

Empati (Emphaty), yaitu membina hubungan yang baik, pemahaman atas kebutuhan individual para pelanggan, dan memberikan pelayanan serta perhatian secara individual pada pelanggannya (Nursalam; 2011). Empati yaitu memberikan perhatian yang tulus dan bersifat individual atau pribadi memiliki pengertian dan pengetahuan tentang pasien, memahami kebutuhan pasien secara spesifik, serta memiliki waktu pengoperasian yang nyaman bagi pasien yang diberikan kepada para pasien dengan berupaya memahami keinginan pasien (Zeitham, 2017).

Hasil penelitian ini diperoleh informasi secara statistik ada hubungan antara empati dengan kepuasan pasien rawat inap di Rumah Sakit Umum Daerah Depati Bahrin Sungailiat Bangka Tahun 2021 ( $\mathrm{p}$ value $=0,038$, OR $=2.927)$ empati baik memiliki kecenderungan kepuasan pasien 2,927 kali lebih besar dibandingkan dengan empati yang kurang baik.

Penelitian ini sejalan dengan penelitian yang dilakukan oleh Juwita Wowor, dkk (2019) yang menunjukan ada hubungan kepuasan pasien dengan daya tanggap di ruang rawat inap Rumah Sakit Cantia Tampaso Baru diperoleh nilai ( $\mathrm{p}$ value = 0,001) diketahui bahwa responden yang memiliki persepsi baik dan puas terhadap mutu pelayanan dalam dimensi empati (empathy) yang diberikan ada sebanyak 48 responden $(92,3 \%)$ sedangkan responden yang memiliki persepsi baik tapi Jurnal Publikasi Kesehatan Masyarakat Indonesia, 55 tidak puas terdapat sebanyak 0 responden (0\%). Responden yang memiliki persepsi tidak baik tapi puas sebanyak 0 responden $(0 \%)$, sedangkan responden yang memiliki persepsi tidak baik dan tidak puas ada sebanyak 4 responden $(7,7 \%)$.

Penelitian ini sejalan dengan penelitian yang dilakukan oleh Mutiara, dkk (2018) yang menunjukan ada hubungan kepuasan pasien dengan daya tanggap di ruang rawat inap Rumah Sakit dr.
H. Abdul Moeloek diperoleh nilai $(\mathrm{p}$ value $=0,003$ ) dengan 60 responden didapatkan 27 responden yang menyatakan empathy baik dan puas terhadap pelayanan rawat inap $(81,8 \%)$ sedangkan responden yang menyatakan assurance kurang baik dan tidak puas terhadap pelayanan rawat inap sebanyak 16 orang $(59,3 \%)$. Berdasarkan hasil penelitian dan teori maka peneliti berpendapat variabel empati berpengaruh dengan kepuasan pasien dalam memberikan pelayanan. kepuasan maupun ketidakpuasan pasien sangat berhubungan dengan persepsi perhatian pasien karena perhatian yang diberikan oleh perawat dapat dirasakan secara langsung oleh pasien dari awal pelayanan sampai akhir pelayanan keperawatan yang pasien dapatkan di ruang rawat inap. Pada dasarnya setiap pasien ingin diperlakukan secara individu atau khusus, dengan demikian rasa perhatian perawat dalam memberikan pelayanan keperawatan alat utama dalam memenuhi harapan pasien akan perlakuan istimewa, sehingga terwujudlah kepuasan pasien terhadap pelayanan keperawatan yang mereka terima.

\section{SIMPULAN}

penelitian ini dapat disimpulkan bahwa, adanya hubungan bermakna antara kehandalan dengan kepuasan pasien rawat inap di RSUD Depati Bahrin Sungailiat, ada hubungan bermakna antara daya tanggap dengan kepuasan pasien rawat inap di RSUD Depati Bahrin Sungailiat, ada hubungan bermakna antara bukti fisik dengan kepuasan pasien rawat inap di RSUD Depati Bahrin Sungailiat, ada hubungan bermakna antara jaminan dengan kepuasan pasien rawat inap di RSUD Depati Bahrin Sungailiat, ada hubungan bermakna antara empati dengan kepuasan pasien rawat inap di RSUD Depati Bahrin Sungailiat.

\section{DAFTAR PUSTAKA}

Andika, F. (2018). Analisis Faktor Kepuasan Pasien BPJS JKRA Dengan Kinerja Perawat Di Rawat Inap Rumah Sakit Umum Daerah Meuraxa Kota Banda Aceh. JOURNAL OF HEALTHCARE TECHNOLOGY AND MEDICINE, 4(2), 207-217.

Alghofiqi, T. (2017). Faktor - faktor Yang Berhubungan Dengan Kepuasan Pelayanan Peserta BPJS Kesehatan di Balai Pengobatan Sukarami Palembang Tahun 2016 (Doctoral dissertation, Universitas Muhammadiyah Palembang).

http://jurnalilmiah.stikescitradelima.ac.id/index.php/JI Vol.5 No.2 Januari 2022 
Amelia, R., \& Rodhiyah, R. (2016). Pengaruh Kualitas Pelayanan Dan Kinerja Karyawan Terhadap Kepuasan Pasien (Studi Kasus Pada Pasien Rawat Inap RS.) jurnal ilmu administrasi Bisnis, 5(4), 163-172.

Butar-Butar, J., \& Simamora, R. H. (2016). Hubungan Mutu Pelayanan Keperawatan dengan Tingkat Kepuasan Pasien Rawat Inap di RSUD Pandan Kabupaten Tapanuli Tengah. Jurnal Ners Indonesia, 6(1), 50-63.

Fadilah, A., \& Yusianto, W. (2019). Hubungan Kualitas Pelayanan Keperawatan Dengan Kepuasan Pasien Rawat Inap Bedah Di RSUD dr. Loekmono Hadi Kudus. Jurnal Keperawatan dan Kesehatan Masyarakat Cendekia Utama, 8(1), 35-44.

Kosnan, W. (2020). Pengaruh Kualitas Pelayanan Terhadap Kepuasan Pasien Rawat Inap Di Rumah Sakit Umum Daerah Kabupaten Merauke. Jurnal Ekonomi, Bisnis, dan Akuntansi, 21(4).

Mutiara, H., Mayasari, D., Fattima, E. T., \& Saputri, C. (2018). Hubungan Mutu Pelayanan Degan Kepuasan Pasien Peserta BPJS di Ruang Rawat Inap Penyakit Dalam RSUD dr. H. Abdul Moeloek. Jurnal Kedokteran Universitas Lampung, 2(1), 31 36.

Mernawati, D., \& Zainafree, I. (2016). Analisis Faktor-Faktor Yang Berhubungan Dengan Tingkat Kepuasan Pasien Rawat Jalan Di Puskesmas Lamper Tengah Kecamatan Semarang Selatan Kota Semarang. Public Health Perspective Journal, 1(1).

Mumu, L. J. (2015). Analisis faktor-faktor yang berhubungan dengan kepuasan pasien di Poliklinik Penyakit Dalam RSUP Prof. Dr. RD Kandou Manado. JIKMU, 5(4).

Oroh, M. E., Rompas, S., \& Pondaag, L. (2014). Faktor-faktor yang berhubungan dengan tingkat kepuasan pasien rawat inap terhadap pelayanan keperawatan di ruang interna RSUD Noongan. Jurnal Keperawatan, 2(2).

Putri, A., \& Putri, H. A. (2015). Faktor - faktor Yang Berhubungan Dengan Kepuasan Pasien Dalam Pelayanan Keperawatan Di Ruang Rawat Inap Interne Pria Dan Wanita RSUD dr. Achmad mochtar Bukit Tinggi Tahun 2014. 'AFIYAH, 2(1).
Rusandy, D. S. (2016). Pengaruh Kualitas Pelayanan Dan Kepercayaan Terhadap Kepuasan Pasien Rawat Inap. (JMK) Jurnal Manajemen dan Kewirausahaan, 1(3), 191205.

Wowor, J; Rumayar, SS; dan Maramis, FRR. 2019. Hubungan Antara Mutu Jasa Pelayanan Kesehatan Dengan Kepuasan Pasien Rawat Inap Di Rumah Sakit Cantia Tompasu Baru. Kesmas 8 (6). 